University of Nebraska - Lincoln

DigitalCommons@University of Nebraska - Lincoln

Agronomy \& Horticulture -- Faculty Publications

Agronomy and Horticulture Department

2000

Bean Leaf Beetle (Coleoptera: Chrysomelidae) Abundance in Soybean Fields Protected and Unprotected by Shelterbelts

\author{
Stephen D. Danielson \\ University of Nebraska-Lincoln, sdanielson1@unl.edu \\ James R. Brandle \\ University of Nebraska-Lincoln, jbrandle1@unl.edu \\ Laurie Hodges \\ University of Nebraska-Lincoln, lhodges1@unl.edu \\ P. Srinivas \\ University of Nebraska-Lincoln
}

Follow this and additional works at: https://digitalcommons.unl.edu/agronomyfacpub

Part of the Plant Sciences Commons

Danielson, Stephen D.; Brandle, James R.; Hodges, Laurie; and Srinivas, P., "Bean Leaf Beetle (Coleoptera: Chrysomelidae) Abundance in Soybean Fields Protected and Unprotected by Shelterbelts" (2000).

Agronomy \& Horticulture -- Faculty Publications. 371.

https://digitalcommons.unl.edu/agronomyfacpub/371

This Article is brought to you for free and open access by the Agronomy and Horticulture Department at DigitalCommons@University of Nebraska - Lincoln. It has been accepted for inclusion in Agronomy \& Horticulture -Faculty Publications by an authorized administrator of DigitalCommons@University of Nebraska - Lincoln. 


\title{
Bean Leaf Beetle (Coleoptera: Chrysomelidae) Abundance in Soybean Fields Protected and Unprotected by Shelterbelts ${ }^{1}$
}

\author{
S. D. Danielson, J. R. Brandle, ${ }^{2}$ L. Hodges $^{3}$ and P. Srinivas \\ Department of Entomology, School of Natural Resource Sciences, ${ }^{2}$ and Department of Horticulture; ${ }^{3}$ \\ Institute of Agriculture and Natural Resources; University of Nebraska-Lincoln, Lincoln; NE 68583 USA
}

J. Entomol. Sci. 35(4): 385-390 (October 2000)

Abstract The bean leaf beetle, Cerotoma trifurcata (Forster) (Coleoptera: Chrysomelidae), is a major insect pest of soybean in Nebraska and throughout much of the Midwest. This insect overwinters in the adult stage in litter in wooded areas such as shelterbelts. Historically, crop producers have been unsure of the merits of shelterbelts, especially if nearby crops are more likely to be infested by insect pests as a result. In this study, bean leaf beetle adults were sampled during the season by visually counting the number of beetles found on soybean plants early in the season and by sweep net sampling once plants were at the V4 stage (approximately $0.33 \mathrm{~m}$ tall). Sampling was done in 1997 and 1998 at the University of Nebraska Agricultural Research and Development Center in Saunders Co. in east-central Nebraska. Beetle counts were compared between shelterbelt-protected and -unprotected fields. In general, bean leaf beetles were more numerous in 1997 than in 1998, with abundance peaks occurring in late-July and early-September in both years. There were significant differences in bean leaf beetle counts from protected and unprotected fields on only three of the 11 and four of the 13 sampling dates in 1997 and 1998, respectively. On the sampling dates when significant differences were found, two of three in 1997 and three of four in 1998 had higher bean leaf beetle abundance in the protected soybean fields. The results of this study indicate a tendency for more bean leaf beetles in shelterbelt-protected soybean fields when differences are found, but beetle numbers were not significantly different between protected and unprotected fields on the majority of sample dates in the two years of this study. This study also reconfirms the presence of two generations of the bean leaf beetle in Nebraska.

Key Words Bean leaf beetle, soybean, shelterbelt, windbreak, Cerotoma trifurcata, Glycine $\max$

In Nebraska, a state with relatively few trees, shelterbelts are an important resource and one that many landowners and crop producers are willing to commit valuable land to accommodate. However, some growers believe that shelterbelts serve as overwintering sites for pests and that crops grown near them are more likely to be damaged by such pests.

Windbreaks or shelterbelts improve crop water-use efficiency (Davis and Norman 1988), distribution of irrigation water, and overall irrigation efficiency (Dickey 1988). Windbreaks have also been shown to enhance the natural insect control (Pasek 1988) and provide wildlife habitat (Johnson and Beck 1988, Johnson et al. 1994). Windbreaks have been shown to have a positive influence on soybean yields (Bald-

'Received 19 August 1999: accepted for publication 31 January 2000. 
win, 1988, Ogbuehi 1980). An economic analysis of the benefits of windbreaks using the net present value indicated that they were an economically attractive investment over a range of options (Brandle et al. 1992).

In Texas, studies conducted on windbreaks indicated that the boll weevil, Anthonomus grandi grandi Boheman, a key pest of cotton overwintered in high numbers in the litter under deciduous trees in windbreaks (Adkisson et al. 1965, Bottrell et al. 1972a). Bottrell et al. (1972b) showed that windbreaks near or adjacent to cotton fields were much more likely to serve as an overwintering habitat for this pest than those some distance from the fields. A management strategy was developed that would lessen the favorability of these habitats for overwintering of the boll weevil (Slosser et al. 1984, Boring et al. 1985). This strategy included planting conifers instead of deciduous species in new windbreaks and thinning existing windbreaks by increasing tree spacing and pruning limbs to prevent trapping leaf litter.

Pedigo (1994) described the bean leaf beetle, Cerotoma trifurcata (Forster), as the most important pest of soybean in the North Central states. Adult bean leaf beetle injury to soybean is considered economic when beetle density ranges from 2 to 9 per plant or sweep depending on growth stage, cost of treatment, and crop value (Hunt et al. 1994). For example, with VC or cotyledon stage soybean, the soybean crop value of $\$ 6.00$ per bushel, and the pest management cost at $\$ 10.00 / 0.4$ ha, the economic threshold is 5 beetles per plant. When soybean plants are in the $\mathrm{V} 1$ stage, the same values provide an economic threshold of 6 beetles per plant. When soybean plants are in the R6 stage, with the same values the economic threshold is 5 beetles per sweep. Insecticide applications are the primary management option when beetles exceed the appropriate economic threshold (Pedigo 1994). Bean leaf beetles overwinter in the adult stage in leaf litter in wooded areas (Boiteau et al. 1980, Loughran and Ragsdale 1986, Jeffords et al. 1983, Payah and Boethel 1985), and at Nebraska's latitude have two generations during the summer months (Kogan et al. 1974, Waldbauer and Kogan 1976, Smelser and Pedigo 1991).

Direct observation of bean leaf beetle adults can be achieved by counting the number of beetles present on plants for a given length of row until the plants reach the V4 stage. However, this technique becomes increasingly inaccurate as plants grow and beetles become more numerous (Kogan et al. 1980). Once plants are beyond the V4 stage, sweep net sampling for adults provides adequate levels of reliability, particularly when relative estimates of beetle abundance are desired (Kogan et al. 1980).

This study was conducted to determine whether bean leaf beetles would be more or less abundant in soybean fields protected by shelterbelts compared to those not protected by shelterbelts.

\section{Materials and Methods}

Sampling was conducted in 1997 and 1998 at the University of Nebraska Agricultural Research and Development Center Agroforestry Farm in Saunders Co., NE. The shelterbelts were planted to a mixture of eastern red cedar, Juniperus virginiana L.; Ponderosa pine, Pinus ponderosa Laws; and green ash, Fraxinus pennsylvanica Marsh., in 1966. The mean height of trees in the shelterbelts was $15 \mathrm{~m}$. Three shelterbelt-protected soybean fields were used in this study. These were designated as protected when shelterbelts were adjacent to the field on at least three sides. Three unprotected fields were used in the study as controls and were designated unprotected when no adjacent shelterbelts were present. Protected and unprotected 
fields were planted at approximately the same time in both years. In 1997, the mean field size was 2 ha with a range of 1.5 to 4 ha and all fields had been planted to soybean the previous year except for one unprotected field that was planted to grain sorghum in 1996. In 1998, the mean field size was 4.6 ha with a range of 1.8 to 7.3 ha and all fields were planted to field corn the previous year except for one unprotected field that was planted to wheat in 1997.

As we suspected that the bean leaf beetle might be more abundant in portions of soybean fields in closer proximity to overwintering sites, fields were stratified with each field being divided into halves designated as east and west and each half was divided again into middle and edge. Bean leaf beetle adults were sampled by visually counting the number of beetles found on soybean plants early in the season and by sampling with 180 degree sweeps of a $38 \mathrm{~cm}$ sweep net when plants reached the V4 growth stage (approximately $0.33 \mathrm{~m}$ tall). In both seasons, early-season sampling was conducted on plants in $2 \mathrm{~m}$ of row at 10 locations in each field in 1997 (i.e. 10 samples per field per sample date). In 1997, 25 sweeps were taken in each stratum of each field on 9 sampling dates from 24 July to 19 September (i.e., 100 sweeps per field per sample date). In 1998, 25 sweeps were taken from each stratum in each field on 8 sampling dates from 8 July to 11 September (i.e., 100 sweeps per field per sample date). Sampling was discontinued when soybean plants began to senesce in the fall.

Data were analyzed using the SAS general linear model (GLM) procedure (SAS Institute 1988). Means were separated using least significant difference (LSD) analysis with a significance level of $P<0.05$.

\section{Results and Discussion}

The bean leaf beetle is a major insect pest of soybean in Nebraska and caused many growers to make insecticide applications to protect soybean seedlings during June in 1997 (pers. commun., K. Glewen, University of Nebraska, Cooperative Extension). Infestation levels remained quite high through the growing season; however, most growers did not treat again later in the season. Few cases of damage that prompted insecticide treatments in 1998 were reported.

In both years of this study, peak bean leaf beetle abundance per generation occurred in late July and early September in both protected and unprotected fields (Fig. 1). These dates approximate peak emergence of the first- and secondgeneration adults. Bean leaf beetles were more abundant in 1997 than in 1998 in the fields we sampled, with the total number collected being 2,013 in 1997 and 1,320 in 1998. There were no significant differences in beetle numbers among the strata in the fields in this study, which may indicate that proximity to overwintering sites is not important in determining whether or not infestations in soybean are high.

In 1997, bean leaf beetle counts were significantly different between protected and unprotected fields on only three of the 11 sampling dates (Fig. 1). Beetles were more abundant in unprotected fields on 2 June $(F=13.86$; $\mathrm{df}=1 ; P>F=0.0005)$ and in the protected fields on 24 July $(F=7.46 ; \mathrm{df}=1 ; P>F=0.0232)$ and 6 August $(F=$ 5.21; df $=1 ; P>F=0.0484$ ). In 1998, beetle density was significantly different between protected and unprotected fields on only four of the 13 sampling dates (Figure 1). Beetles were more abundant in protected fields on 13 June ( $F=12.94$; df $=1 ; P>F=0.0026), 21$ July $(F=4.78 ; \mathrm{df}=1 ; P>F=0.045)$, and 18 August $(F=$ 

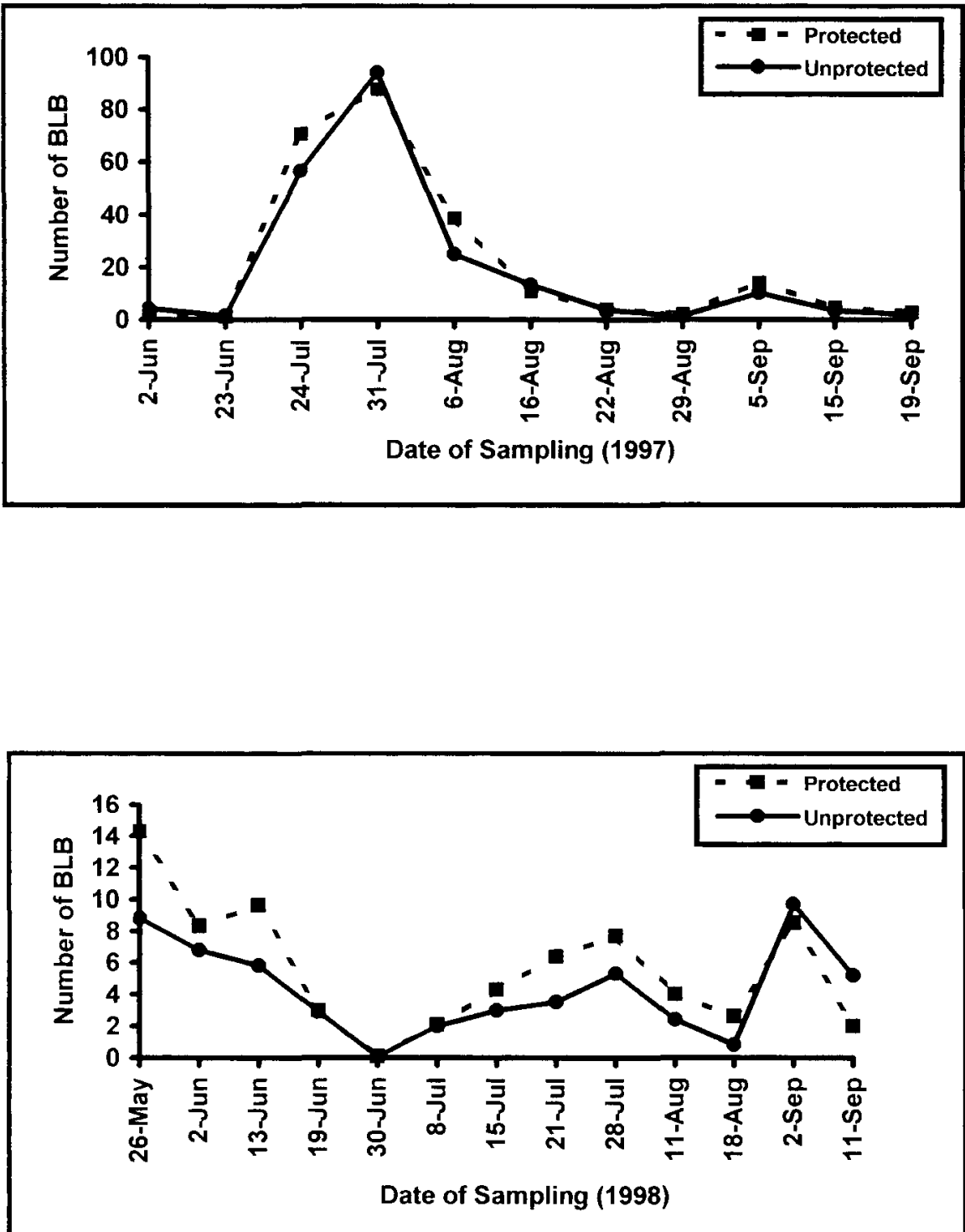

Fig. 1. Bean leaf beetles captured in soybean fields protected and unprotected by shelterbelts in 1997 and 1998. Counts represent the mean number of bean leaf beetle adults captured per 25 sweeps, except for June 2 and 23 in 1997 and May 26 to June 30 in 1998 which are the mean number of beetles per $2 \mathrm{~m}$ of row. 
18.33; $\mathrm{df}=1 ; P>F=0.0007)$ while they were more abundant in the unprotected fields on 11 September $(F=5.88 ; \mathrm{df}=1 ; P>F=0.0285)$.

Our results do not provide economic evidence regarding bean leaf beetle damage to either shelterbelt-protected or -unprotected soybean fields. They do, however, show that bean leaf beetle abundance was not significantly different between protected and unprotected soybean fields on the majority of sample dates during the two years of this study. When significant differences were found, on two of the three sample dates in 1997 and three of the four sample dates in 1998 more bean leaf beetles were found in the shelterbelt-protected fields.

Growers do have some reason to believe that trees compete with crop plants immediately adjacent to the shelterbelt for moisture, nutrients, and sunlight, however, evidence suggests that such effects do not extend beyond the first few rows of crop plants and that yields increase thereafter (Nieto-Cabrera 1998, Hou 1999). Preliminary studies that we have conducted indicate that the bean leaf beetles overwintering in shelterbelts in eastern Nebraska are generally in the litter under deciduous rather than coniferous trees as was found by Bottrell et al. (1972b) with the boll weevil in Texas (S.D.D., unpubl, data). This is also encouraging as many of the shelterbelts in this portion of the midwest are dominated by the conifer, eastern red cedar, J. virginiana. The non-pest related benefits of shelterbelts to crop production in the North Central states have been documented by Brandle et al. (1994) and others. However, before this study, little evidence had been obtained regarding potential pest problems related to field proximity to shelterbelts.

\section{Acknowledgments}

We thank F. P. Baxendale and T. E. Hunt for reviewing this manuscript. The authors are also grateful to S. Wreed, K. Knop, and J. Brandle for their technical assistance. Support for this research was provided by the University of Nebraska ARDC Interdisciplinary Farm Project. This is contribution 12711 of the journal series of the Agricultural Research Division, University of Nebraska-Lincoln.

\section{References Cited}

Adkisson, P. L., J. W. Davis, W. L. Owen and D. R. Rummel. 1965. Evaluations of the 1964 diapause boll weevil program on the High Plains of Texas. Texas Agric. Exp. Sta., Dept. Entomol. Tech. Rep. 1. 59 pp.

Baldwin, C. S. 1988. The influence of field windbreaks on vegetable and specialty crops, $\mathrm{Pp}$. 191-203. In J. R. Brandle, D. L. Hintz and J. W. Sturrock (eds), Windbreak technology. Elsevier, Amsterdam.

Boiteau, G., J. R. Bradley, Jr. and J. W. Van Duyn. 1980. Bean leaf beetle: temporal and macro-spatial distribution in North Carolina. J. Georgia Entomol. Soc. 15: 151-163.

Boring, E. P., III, J. E. Slosser and R. J. Fewin. 1985. Windbreak management to reduce overwintering boll weevil habitat. Texas Agric. Ext. Ser. Leaf 2135

Bottrell, D. G., D. R. Rummel and P. L. Adkisson. 1972a. Spread of the boll weevil into the High Plains of Texas. Environ. Entomol. 1: 136-140.

Bottrelt, D. G., J. R. White, D. G. Moody and D. D. Hardee. 1972b. Overwintering habitats of the boll weevil in the Rolling Plains of Texas. Environ. Entomol. 1: 633-638.

Brandle, J. R., B. B. Johnson and T. Akeson. 1992. Field windbreaks: are they economical? J. Prod. Agric. 5: 393-398.

Davis, J. E. and J. M. Norman. 1988. Effects of shelter on plant water use. Agric. Ecosyst. Environ. 22/23: 393-402. 
Dickey, G. L. 1988. Crop water use and water conservation benefits from windbreaks. Agric. Ecosyst. Environ. 22/23: 381-392.

Hou, Q. 1999. Soil moisture within the windbreak/crop interface and a comparison of three types of sensors for measuring soil water content. M.S. Thesis. University of Nebraska, Lincoln, NE. $65 \mathrm{pp}$

Hunt, T., J. F. Witkowski, R. Wright and K. J. Jarvi. 1994. The bean leaf beetle in soybeans. NebGuide G90-974. Nebraska Coop. Ext., Lincoln, NE.

Jeffords, M. R., C. G. Helm and M. Kogan. 1983. Overwintering behavior and spring colonization of soybean by the bean leaf beetle (Coleoptera: Chrysomelidae) in Illinois. Environ. Entomol. 12: 1459-1463.

Johnson, R. J. and M. M. Beck. 1988. Influences of shelterbelts on wildlife management and biology. Agric. Ecosyst. Environ. 22/23: 301-335.

Johnson, R. J., M. M. Beck and J.R. Brandle. 1994. Windbreaks for people: the wildlife connection. J. Soil and Water Cons. 49: 546-550.

Kogan, M., W. G. Ruesink and K. McDowell. 1974. Spatial and temporal distribution patterns of the bean leaf beetle, Cerotoma trifurcata (Forster), on soybeans in Illinois. Environ. Entomol. 3: 607-617.

Kogan, M., G. P. Waldbauer, G. Boiteau and C. E. Eastman. 1980. Sampling bean leaf beetles on soybean, Pp, 201-236. In Kogan, M. and D. C. Herzog (eds.), Sampling Methods in Soybean Entomology. Springer-Verlag. NY.

Loughran, J. C. and D. W. Ragsdale. 1986. Life cycle of the bean leaf beetle, Cerotoma trifurcata (Coleoptera: Chrysomelidae), in southern Minnesota. Ann. Entomol. Soc. Am. 79: 34-38.

Nieto-Cabrera, C. 1998. Above and below-ground competition for solar radiation and soil moisture in a windbreak-soybean system. Ph.D. Diss., Univ. Nebraska, Lincoln, NE. 192 pp.

Ogbeuhi, S. N. 1980. Influence of windbreak-shelter on soybeans, Glycine max (L.) Merrill, Ph.D. Diss. Univ. Nebraska, Lincoln, NE. 95 pp.

Pasek, J. E. 1988. Influence of wind and windbreaks on local dispersal of insects. Agric. Ecosyst. Environ. 22/23: 539-554.

Payah, W. S. and D. J. Boethel. 1985. Overwintering bean leaf beetles, Cerotoma trifurcata (Forster) (Coleoptera: Chrysomelidae): density of populations, temporal patterns of movement, and survival. Environ. Entomol. 14: 65-73.

Pedigo, L. P. 1994. Bean leaf beetle, Pp. 42-44. In Higley, L. G. and D. J. Boethel (eds.), Handbook of Soybean Insect Pests. Entomol. Soc. Amer., Lanham, MD

SAS Institute. 1988. SAS/STAT user's guide: statistics, release 6.03 ed. SAS Institute, Cary, $\mathrm{NC}$

Slosser, J. E., R. J. Fewin, J. R. Price, L. J. Meinke and J. R. Bryson. 1984. Potential of shelterbelt management for boll weevil (Coleoptera: Curculionidae) control in the Texas Rolling Plains. J. Econ. Entomol. 77: 377-385.

Smelser, R. B. and L. P. Pedigo. 1991. Phenology of Cerotoma trifurcata on soybean and alfalfa in central lowa. Environ. Entomol. 20: 514-519.

Waldbauer, G. P. and M. Kogan. 1976. Bean leaf beetle: phenological relationship with soybean in Illinois. Environ. Entomol. 5: 35-44. 